\title{
Quantitative variables applied to phenological studies of Sargassum vulgare C. Agardh (Phaeophyceae - Fucales) from Ilha Grande Bay, State of Rio de Janeiro
}

\author{
MARIA TERESA M. DE SZÉCHY ${ }^{1,2}$, MARON GALLIEZ ${ }^{1}$ and MÁRCIA I. MARCONI ${ }^{1}$
}

(received: August 5, 2004; accepted: December 29, 2005)

\begin{abstract}
Quantitative variables applied to phenological studies of Sargassum vulgare C. Agardh (Phaeophyceae Fucales) from Ilha Grande Bay, State of Rio de Janeiro). The suitability of quantitative variables for phenological studies was evaluated in a population of the brown seaweed Sargassum vulgare from "Praia das Gordas", Angra dos Reis, Ilha Grande Bay, state of Rio de Janeiro. From June 1998 to May 1999, twenty adult individuals were randomly sampled at bimonthly intervals. Fifteen variables related to the vegetative and reproductive development of perennial and non-perennial parts of the individuals were quantified. Variables related to the non-perennial parts were more useful than those related to the perennial parts, because they showed a clear variation over the year. Vegetative development declined from June to October, and increased from October to February, when maximum median values of thallus height, total dry mass, non-perennial parts dry mass, and degree of branching were reached. This pattern coincided with those described for other species of the genus from warm temperate regions. Thallus height, a usually employed character in other phenological studies of Sargassum, showed lower coefficient of variation (53.2\%) than those related to dry mass (72.0\% to $182.3 \%$ ). Peak of reproduction occurred from June to August, according to the following variables: fertile primary lateral branches number and dry mass and receptacles dry mass. Nonperennial parts dry mass and receptacles dry mass are recommended for phenological studies of $S$. vulgare. This methodological procedure avoids the sampling of the whole individual and warrants its regeneration from the perennial parts.
\end{abstract}

Key words - methodology, reproduction, Sargassum, temporal variation, vegetative development

RESUMO - (Variáveis quantitativas aplicadas a estudos fenológicos de Sargassum vulgare C. Agardh (Phaeophyceae Fucales) da Baía da Ilha Grande, Estado do Rio de Janeiro). A população de Sargassum vulgare da Praia das Gordas, Angra dos Reis, Baía da Ilha Grande, Estado do Rio de Janeiro, foi estudada de junho de 1998 a maio de 1999, a fim de avaliar a adequação de variáveis quantitativas para estudos fenológicos desta alga parda. Vinte indivíduos adultos foram coletados aleatoriamente a intervalos de dois meses. Quinze variáveis relacionadas ao desenvolvimento vegetativo e reprodutivo das partes perenes e não perenes dos indivíduos foram quantificadas. As variáveis relacionadas às partes não perenes mostraram claramente variação ao longo do ano, sendo mais úteis do que aquelas relacionadas às partes perenes. O desenvolvimento vegetativo diminuiu na população de junho a outubro e aumentou de outubro a fevereiro, quando valores medianos foram máximos para altura do talo, massa seca total, massa seca das partes não perenes e grau de ramificação. Esse padrão coincidiu com os descritos para outras espécies do gênero em regiões temperadas quentes. A altura do talo, geralmente empregada em outros estudos fenológicos de Sargassum, mostrou menor coeficiente de variação $(53,2 \%)$ do que os das variáveis relacionadas à massa seca (72,0\% a 182,3\%). Pico de reprodução foi detectado de junho a agosto, de acordo com as variáveis: número e massa seca de ramos laterais primários férteis e massa seca dos receptáculos. Massa seca das partes não perenes e massa seca dos receptáculos são as variáveis recomendadas para estudos fenológicos de $S$. vulgare, pois não requerem coletas do indivíduo inteiro, possibilitando regeneração a partir das partes perenes.

Palavras-chave - desenvolvimento vegetativo, metodologia, reprodução, Sargassum, variação temporal

\section{Introduction}

The genus Sargassum C. Agardh (Phaeophyceae, Fucales) is a frequent macroscopic alga of the marine sublittoral zone of tropical and warm temperate regions (Lüning 1990). In the southeastern coast of Brazil, the

\footnotetext{
1. Universidade Federal do Rio de Janeiro, Centro de Ciências da Saúde, Instituto de Biologia, Departamento de Botânica, bloco A, Ilha do Fundão, 21941-590 Rio de Janeiro, RJ, Brasil.

2. Corresponding author: szechy@biologia.ufrj.br
}

ecological importance of this brown seaweed has been recognized as it provides different resources for other members of the littoral marine communities, especially for the phytal (Ostini et al. 1992, Dubiaski-Silva \& Masunari 1995, Széchy et al. 2001). Great abundance of Sargassum vulgare C. Agardh $\left(587 \mathrm{~g} \mathrm{~m}^{-2}\right.$ of dry mass) has been reported for populations from the state of Rio de Janeiro, particularly for those not subjected to disturbances (Széchy \& Paula 2000).

While members of the genus have been the subject of phenological studies in many regions of the world 
(Thomas \& Subbaramaiah 1991, Vuki \& Price 1994, Pacheco-Ruíz et al. 1998, Yoshida et al. 1998, Gillespie \& Critchley 1999, Hurtado \& Ragaza 1999, Stiger \& Payri 1999), there have been few reports on Sargassum seasonality in the southern Atlantic Ocean. In Brazil, members of Sargassum have been relatively neglected in ecological studies, despite some local efforts. Paula \& Oliveira Filho (1980) described phenological aspects of two S. cymosum C. Agardh populations from Ubatuba, state of São Paulo, which showed higher values of thallus height and biomass in late spring, and lower values in summer or early fall, depending on the studied population. Eston \& Bussab (1990) concluded that $S$. stenophyllum (Mertens) Martius was a perennial and slow-growing species, recovering its dense canopy regardless of season, during a three-year experiment in a rocky sublittoral community of Ubatuba. DubiaskiSilva \& Masunari (2000) studied a bed of S. cymosum from Bombinhas, state of Santa Catarina, which had maximum values of biomass in spring, when the tallest plants were registered. Godoy \& Coutinho (2002) referred to the seasonal variation of $S$. furcatum Kuetzing found in Cabo Frio Island, in the northern coast of the state of Rio de Janeiro, stressing that the individuals grew rapidly from January to March, when they dominated almost all the sandstone formation, and then they became almost absent during winter. Reis et al. (2003) reported the temporal variation in the biomass of the Sargassum species from a bed situated at Itacuruçá Island, Sepetiba Bay, State of Rio de Janeiro. Sargassum dry mass increased from October 1994 to February 1995, and then decreased continuously, in an unexpected way. Amado Filho et al. (2003) described the temporal variation in the structure of sublittoral communities from five localities in Sepetiba Bay. They found the highest values for Sargassum spp. biomass in winter, at Itacuruçá Island; however, greater abundance of Sargassum spp. was observed in spring and summer, at the other localities.

It can be noted that the quantitative variables used for the analysis of vegetative development of Brazilian Sargassum populations have been the height or the dry mass of the whole individuals, obtained always by destructive samplings. On the other hand, the quantitative analysis of reproductive development of the populations has been essentially based on the proportion of individuals with receptacles. Comparisons among different Sargassum populations and establishment of phenological patterns are difficult to be made because there is no methodological standardization.
Ilha Grande Bay, as well as other bays along the southeastern coast of Brazil, has been subjected to an increasing pollution of different kinds (Tommasi 1990). Ecological studies of the Sargassum species, common members of the rocky communities, are important for the monitoring of the Ilha Grande Bay marine environment.

This study aimed to describe the temporal variation of different quantitative variables of a $S$. vulgare population from Angra dos Reis, Ilha Grande Bay, in order to select suitable phenological variables for future studies of the species.

\section{Material and methods}

Study site - Angra dos Reis is located in the southeastern coast of Brazil, in the state of Rio de Janeiro (2301' $19^{\prime \prime}$ S and $44^{\circ} 19^{\prime} 58^{\prime \prime} \mathrm{W}$ ) (figure 1). The city is famous for the exuberance and beauty of the nearby Atlantic Rain Forest and for its calm sea, which enhances tourism activities, including diving and fishing. The study site is located at "Praia das Gordas", near "Colégio Naval" and in front of Maia's Island. "Praia das Gordas" is a small beach, subjected to a moderate degree of wave exposure. On the right side of the beach, the sublittoral zone is occupied by boulders of different sizes, where a monospecific bed of Sargassum vulgare C. Agardh is permanently growing from the fringe of the sublittoral zone to a depth of around $2 \mathrm{~m}$.

For the coastal region of the state of Rio de Janeiro, both air temperature and rainfall are usually higher in summer

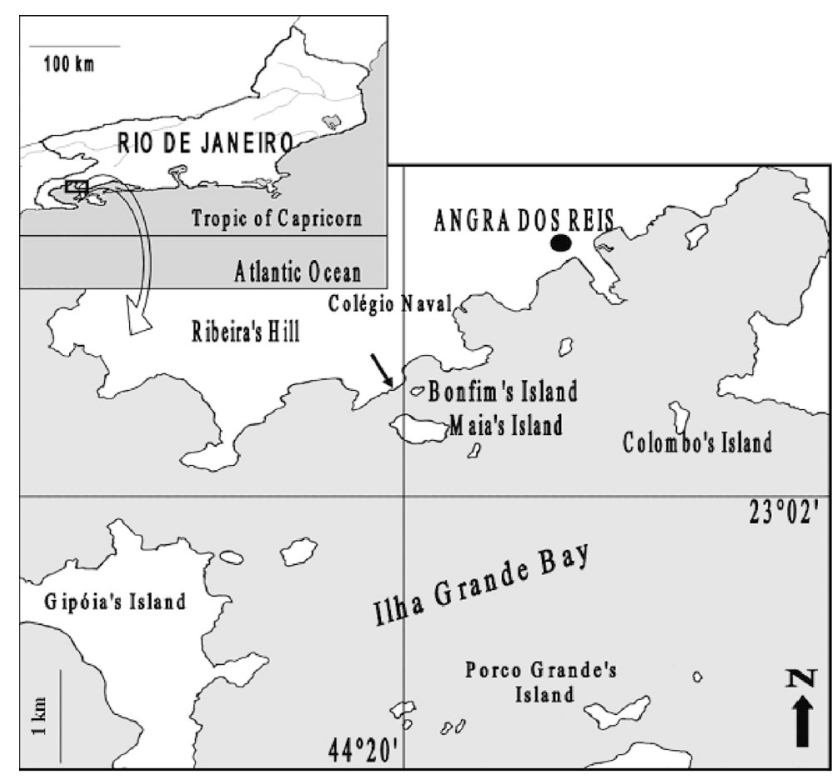

Figure 1. Location of the study site at "Praia das Gordas" $(\rightarrow)$, Angra dos Reis, Ilha Grande Bay, southern coast of the state of Rio de Janeiro. 
(Nogueira et al. 1987, Pereira 1994), as occurred for Angra dos Reis during the period of June 1998 to May 1999, when the highest mean values of maximum and minimum daily air temperatures were registered in February 1999 and January 1999, respectively (Diretoria de Hidrografia e Navegação da Marinha do Brasil, unpublished data) (figure 2A). Rainfall was more expressive during spring and summer; from August to September 1998, the rainfall showed an abrupt increase, reaching its highest value in December 1998 (241.1 mm month ${ }^{-1}$ ) (Instituto Nacional de Meteorologia, unpublished data) (figure 2B).

Seawater temperature in the coastal region (depths inferior to $20 \mathrm{~m}$ ) where the study area is situated, endures an outstanding seasonal variation concerning its vertical distribution: in summer, there is stratification of the water column into two layers; in winter, the water column is more uniform. This dynamics can be related to the seasonal variations in sun radiation intensity and to the wind pattern (Castro Filho 1994).

Northeastern winds are most frequent in summer, and southwestern winds in winter, when strong winds are common and waves with more energy are formed (Pereira 1994).

The highest number of days with the lowest tides occurring during the day (daytime minimum tides) was registered in autumn and winter, especially in June and July 1998 and May 1999, when some Sargassum individuals were exposed to air during the day (personal observations). In summer, this situation was inverted, as daytime minimum tides were less frequent, especially in December 1998 and January 1999, when daytime minimum tides did not occur at all (Diretoria de Hidrografia e Navegação da Marinha do Brasil, unpublished data) (figure 2C).

Sampling method and data analysis - Sampling was carried out bimonthly, during periods of low waters of spring tides, over a period of 12 months, from June 1998 to May 1999.

At each sampling time, a $20 \mathrm{~m}$ rope was laid across the Sargassum bed, parallel to the coastline. This rope was positioned at the middle portion of the vertical extension of the Sargassum bed. To indicate which Sargassum individuals should be collected, tags were randomly placed along this rope, using a random number table. At each sampling time, Sargassum adult individuals, which were the nearest ones to each of the 20 tags of that rope, were scraped off the rocks, including as much of their holdfast as possible. Individuals were considered as adult when they had the following morphological characteristics: thallus height $>3.0 \mathrm{~cm}$ and main axes maximum length $>1.0 \mathrm{~cm}$. Each individual was placed in plastic bags and fixed with formalin. Care was taken to remove the epiphytes and sediments from the individuals.

Each collected individual was separated into: holdfast and main axes (perennial parts) and non-fertile and fertile primary lateral branches (non-perennial parts), using terminology suggested by Paula (1988). The receptacles were cut off from the fertile branches. Then each individual was analysed for 15 quantitative variables, obtained by counting,
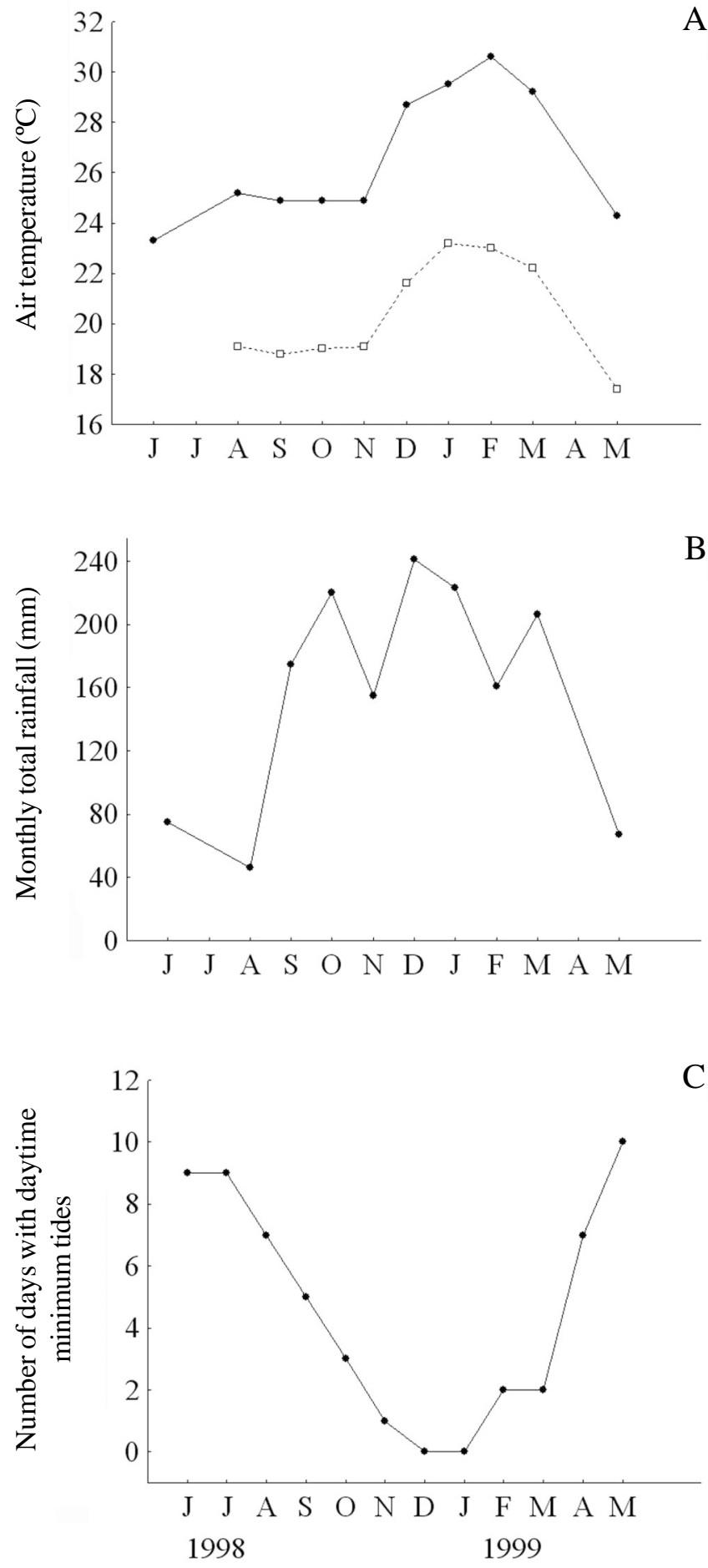

Figure 2. Monthly abiotic data at Angra dos Reis city, near the study site, during the period of April 1998 to May 1999. A. Mean values of maximum daily air temperatures $(\bullet)$ and minimum daily air temperatures $(\square)$. B. Total rainfall. C. Number of days with daytime minimum tides (tides inferior or equal to $0.2 \mathrm{~m}$ which occurred between 10:00 to 14:00). Data provided by "Instituto Nacional de Meteorologia" (Inmet) for Angra dos Reis city and by "Diretoria de Hidrografia e Navegação da Marinha do Brasil" (DHN), for Angra dos Reis Harbor. 
measuring and weighting the different parts. These variables were divided into three categories: 1) vegetative variables: thallus height from the holdfast to the tallest primary lateral branch, main axes maximum length; main axes number, nonfertile primary lateral branches number, holdfast dry mass, main axes dry mass and non-fertile primary lateral branches dry mass; 2) reproductive variables: fertile primary lateral branches number, fertile primary lateral branches dry mass and receptacles dry mass; and 3) composed variables, such as degree of branching and reproductive effort (table 1). The total number of branches, including main axes and fertile and non-fertile primary lateral branches, was used to estimate the degree of branching of the individuals. Reproductive effort was expressed in terms of the proportion of reproductive biomass to the total vegetative biomass (Mathieson \& Guo 1992), by calculating the percentage of the non-perennial parts dry mass of each individual invested in receptacles.

The dry masses of the different parts of each individual (holdfast, main axes, non-fertile primary lateral branches, fertile primary lateral branches without the receptacles and receptacles) were obtained after putting them separately in an oven at $80^{\circ} \mathrm{C}$ until constant weight was obtained.

The definition of the degree of suitability of each variable for phenological studies was based on two criteria: 1) range of variation throughout the study period; 2) range of variation at each sampling time. Variables with great variation throughout the study period and little variation at each sampling time were considered as the most suitable ones.
Data variability throughout the study period was analysed by coefficients of variation, considering all the studied individuals.

Boxplots were made for some variables representing the vegetative and reproductive development of the individuals in order to show their variation throughout the study period (median values) and also to represent their variation at each sampling time (through the ranges of the measurements).

\section{Results}

Sargassum vulgare C. Agardh adult individuals reached $42.9 \mathrm{~cm}$ height, but mean value of this variable throughout the study was approximately $13.0 \mathrm{~cm}$. They were generally highly branched (maximum degree of branching per individual $=136$ branches). In each individual, biomass (expressed as dry mass) was concentrated in the non-perennial parts when compared to the perennial parts. Considering the non-perennial parts of the individuals, non-fertile primary lateral branches were usually more numerous than the fertile ones. Throughout the study, the highest value of reproductive effort per individual was $28.57 \%$ (table 1).

Vegetative and reproductive variables, as well as composed variables, showed a considerable temporal variation (coefficients of variation higher than 50\%,

Table 1. Phenological data for Sargassum vulgare C. Agardh adult individuals from "Praia das Gordas", Angra dos Reis, state of Rio de Janeiro, during the period of June 1998 to May 1999, based on vegetative, reproductive and composed variables. Minimum value (Min.), arithmetic mean (Mean), maximum value (Max.), and coefficient of variation $(C V)(n=140)$.

\begin{tabular}{|c|c|c|c|c|c|}
\hline Variables (units) & Symbols & Min. & Mean & Max. & $C V(\%)$ \\
\hline \multicolumn{6}{|l|}{ Vegetative variables } \\
\hline Thallus height (cm) & & 3.1 & 12.8 & 42.9 & 53.2 \\
\hline Holdfast dry mass (g) & $\mathrm{a}$ & 0.01 & 0.09 & 0.40 & 86.4 \\
\hline Main axes maximum length $(\mathrm{cm})$ & & 1.8 & 2.7 & 3.7 & 23.1 \\
\hline Main axes number & $\mathrm{b}$ & 1 & 6 & 20 & 55.1 \\
\hline Main axes dry mass (g) & $\mathrm{c}$ & 0.01 & 0.05 & 0.17 & 72.0 \\
\hline Non-fertile primary lateral branches number & $\mathrm{d}$ & 5 & 41 & 122 & 59.3 \\
\hline Non-fertile primary lateral branches dry mass (g) & e & 0.01 & 0.83 & 9.06 & 157.8 \\
\hline \multicolumn{6}{|l|}{ Reproductive variables } \\
\hline Fertile primary lateral branches number & $\mathrm{f}$ & 0 & 6 & 44 & 155.1 \\
\hline Fertile primary lateral branches dry mass (g) & $\mathrm{g}$ & 0.00 & 0.08 & 0.89 & 178.1 \\
\hline Receptacles dry mass $(\mathrm{g})$ & $\mathrm{h}$ & 0.00 & 0.02 & 0.21 & 182.3 \\
\hline \multicolumn{6}{|l|}{ Composed variables } \\
\hline Perennial parts dry mass $(\mathrm{g})$ & $\mathrm{i}=(\mathrm{a}+\mathrm{c})$ & 0.01 & 0.14 & 0.46 & 76.0 \\
\hline Non-perennial parts dry mass (g) & $j=(e+g+h)$ & 0.01 & 0.98 & 9.72 & 152.4 \\
\hline Total dry mass & $=(\mathrm{i}+\mathrm{j})$ & 0.01 & 1.00 & 9.97 & 145.6 \\
\hline Reproductive effort (\%) & $=\mathrm{h} / \mathrm{j} 100$ & 0.00 & 2.30 & 28.57 & 207.3 \\
\hline Degree of branching & $=(b+d+f)$ & 7 & 48 & 136 & 57.8 \\
\hline
\end{tabular}


except for main axes maximum length) (table 1). Variables related to non-perennial parts dry mass of the individuals showed the highest coefficients of variation, especially those related to the reproductive development of the individuals, such as reproductive effort $(C V=207.3 \%)$, receptacles dry mass $(C V=182.3 \%)$ and fertile primary lateral branches dry mass $(C V=178.1 \%)$. Non-perennial parts dry mass varied from $0.01 \mathrm{~g}$ to $9.72 \mathrm{~g}$ per individual, while perennial parts dry mass varied from $0.01 \mathrm{~g}$ to $0.46 \mathrm{~g}$ per individual. On the other hand, main axes maximum length, main axes number, thallus height, degree of branching and nonfertile primary lateral branches number showed the lowest coefficients of variation over the year (table 1), being less suitable for the evaluation of the phenological aspects of the population.

Median values of thallus height, total dry mass and non-perennial parts dry mass showed a clear tendency to increase and decrease over the year. The highest values (median values and outliers) for thallus height, total dry mass and non-perennial parts dry mass occurred in February 1999, while the lowest median values occurred in October 1998 (figure 3A-C). Great ranges of variation of these variables could be noted (figure 3A-C), especially in February and April 1999.

The primary lateral branches number per individual was highly variable in the population, at each sampling time, particularly from October 1998 to the end of the

A
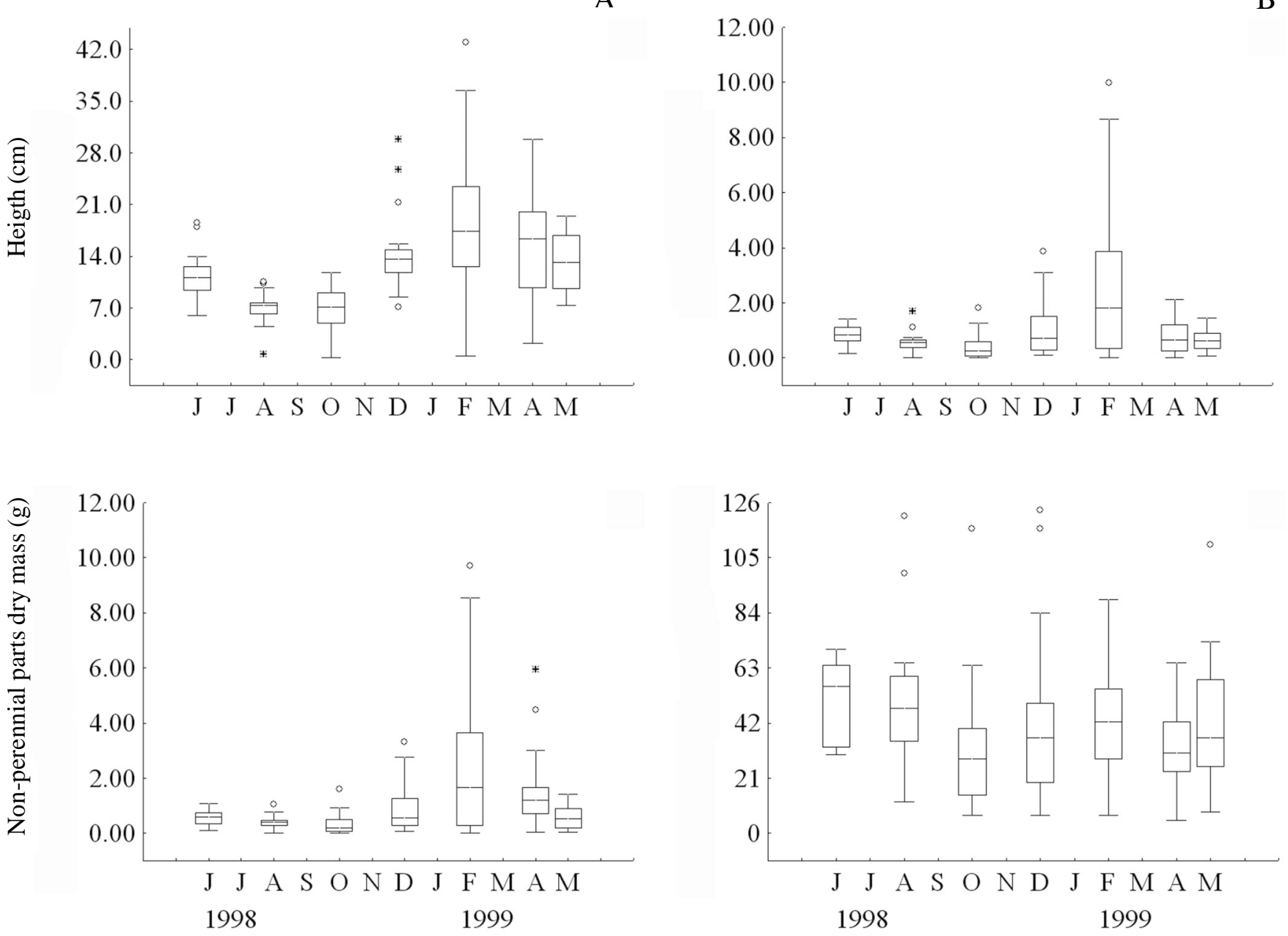

Figure 3. Boxplots representing the variation of the vegetative development in a Sargassum vulgare C. Agardh population from Angra dos Reis, based on vegetative and composed variables. A. Thallus height $(\mathrm{cm})$. B. Total dry mass of the individual (g). C. Non-perennial parts dry mass per individual (g). D. Primary lateral branches number per individual (non-fertile + fertile branches). (Vertical lines $=$ range of measurements; central boxes $=$ inter-quartile ranges; central horizontal lines $=$ median values; $*$ and $\mathrm{O}=$ outlying values). 
study period (figure 3D). Considering the median values, this variable decreased from June to October 1998; after this period, the population showed a slight increase, reaching its peak in February 1999, although not as markedly as in the other variables.

Based on variables related to the non-perennial parts and despite the variations observed among the individuals at each sampling time, the vegetative development of the population could be divided into three phases: 1) a decrease from June to August 1998; 2) a considerable increase from October to December 1998 and February 1999; and 3) a decrease from February to May 1999. Thallus height was the variable that more clearly followed this variation pattern, with medians varying from $7.2 \mathrm{~cm}$ (October) to $17.4 \mathrm{~cm}$ (February) (figure 3A).

A decrease in vegetative development was also observed for the perennial parts of the individuals, from June to October 1998 (figure 4A, B). The median values of the perennial parts dry mass (figure 4A) showed a considerable decrease during this period. Great ranges of variation of these vegetative variables were noted at all the sampling times (figure 4A, B).

Fertile individuals (with receptacles) were found throughout the year. The proportion of fertile individuals in the population was higher in June (75\%) and August 1998 (60\%) and lower in October 1998 (35\%) and in April 1999 (30\%). The proportion of fertile primary lateral branches per individual was higher in June 1998 and in April 1999 (23\% and 21\% respectively) and lower in October 1998 (4\%) (figure 5).

The highest median values for fertile primary lateral branches dry mass, fertile primary lateral branches number and receptacles dry mass per individual occurred in June and August 1998, while the lowest values occurred in October 1998 (figure 6A-C). Median values of reproductive effort were also higher in June and August 1998 (3.18\% and 3.51\% respectively); in the remaining sampling times, median values of reproductive effort showed great ranges of variation. Based on the analysed variables, the reproductive development of the population could be divided into two phases: 1) a clear decrease from August to October 1998; and 2) a slight increase throughout the remaining study period. Fertile primary lateral branches dry mass and receptacles dry mass per individual were the variables which have most clearly followed this variation pattern. The fertile primary lateral branches number per individual (figure 6C) and the reproductive effort were highly variable throughout the study period $(C V=155.1 \%$ and $207.3 \%$ respectively) (table 1 ). These variables also showed great ranges of variation at the sampling times, especially in June and August 1998 (fertile primary lateral branches number per individual, figure 6C) and in December 1998 and February 1999 (reproductive effort).

So, the studied population showed the same pattern of temporal variation for vegetative and reproductive development, both decreasing from June to October, and increasing from October to February. However, the maximum values for the variables related to the vegetative and reproductive development did not occur at the same time. While thallus height, total dry mass and non-perennial parts dry mass showed the highest medians in February 1999, fertile primary lateral branches dry mass and number and receptacles dry mass showed the highest medians from June to August 1998.
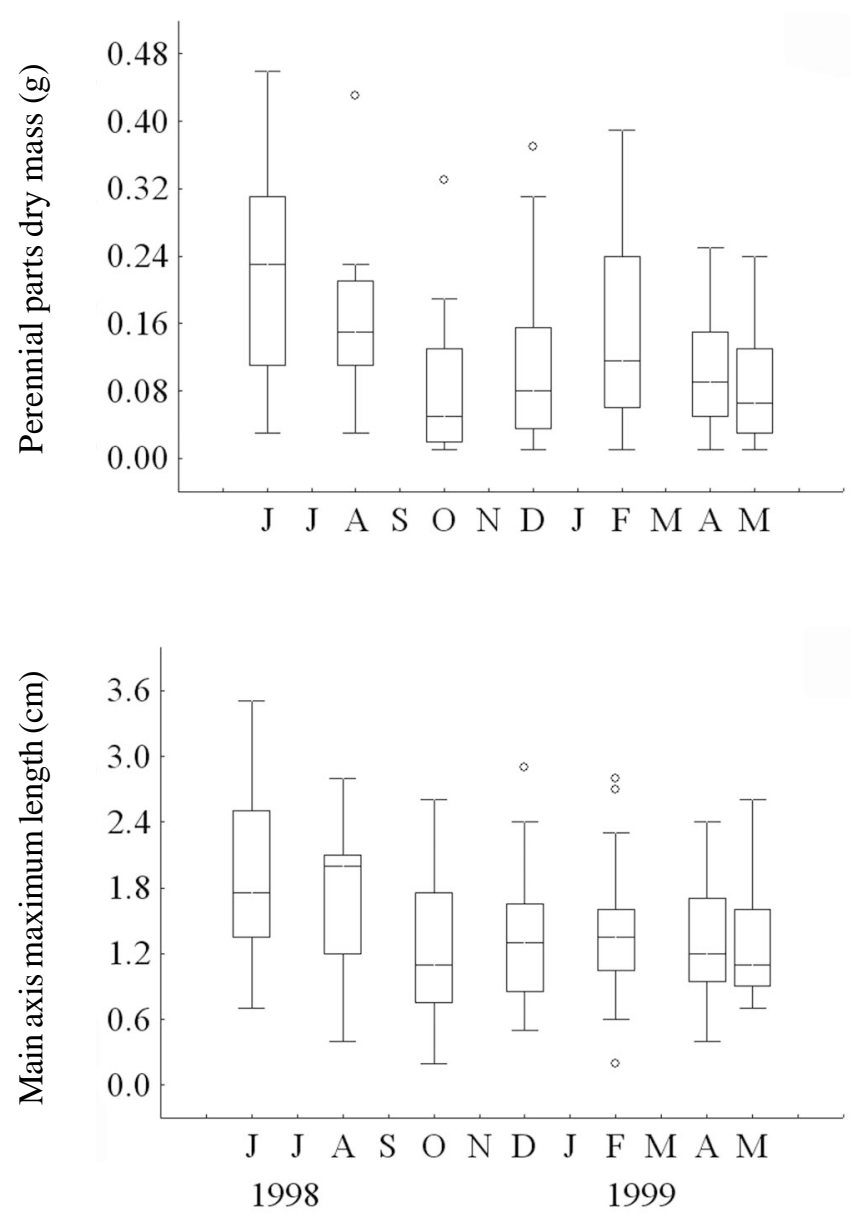

Figure 4. Boxplots representing the variation of the vegetative development in a Sargassum vulgare C. Agardh population from Angra dos Reis, based on vegetative variables related to the perennial parts. A. Perennial parts dry mass per individual $(\mathrm{g})$. B. Main axes maximum length $(\mathrm{cm})$. (Vertical lines = range of measurements; central boxes $=$ inter-quartile ranges; central horizontal lines = median values; $\mathrm{O}=$ outlying values). 


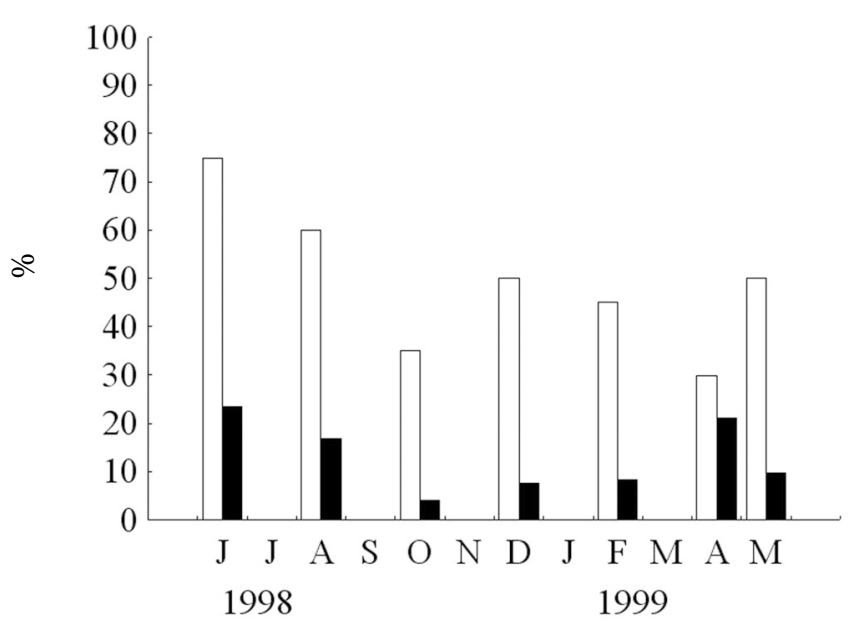

Figure 5. Temporal variation of the numbers of fertile individuals and fertile primary lateral branches per individual in a Sargassum vulgare population from Angra dos Reis. ( $\square=$ proportion of fertile individuals $(n=20)$; $\mathbf{\square}=$ mean proportion of primary lateral branches per individual $(n=20))$.

\section{Discussion}

Sargassum vulgare C. Agardh population from "Praia das Gordas" is similar to other perennial species of the genus, regarding the persistence of the holdfast and the main axes during more than one year (Umezaki 1974, 1984, Paula \& Oliveira Filho 1980, Espinoza 1990, Eston \& Bussab 1990, Thomas \& Subbaramaiah 1991). The decrease in thallus height, primary lateral branches dry mass and primary lateral branches total number of $S$. vulgare adult individuals, after their reproductive peaks in June-August 1998, can be related to the senescence of the fertile primary lateral branches. Fertile primary lateral branches become senescent and are released (Ang Junior 1985). Then, the perennial parts of the Sargassum individuals may regenerate with time, producing new primary lateral branches (Fagerberg \& Dawes 1976, Paula \& Eston 1987, Givernaud et al. 1990).

Holdfast and main axes have a tendency of gradual increasing in dimensions with the age of the individuals under favorable conditions (Espinoza 1990). This tendency, however, could not be noted in the $S$. vulgare population from "Praia das Gordas", considering that the variables related to the perennial parts of the individuals showed lower medians at the end than at the beginning of the study period. It is likely that adverse weather conditions in the winter 1998, such as storm waves, had eliminated the taller and older individuals of the population, leaving available substratum for the
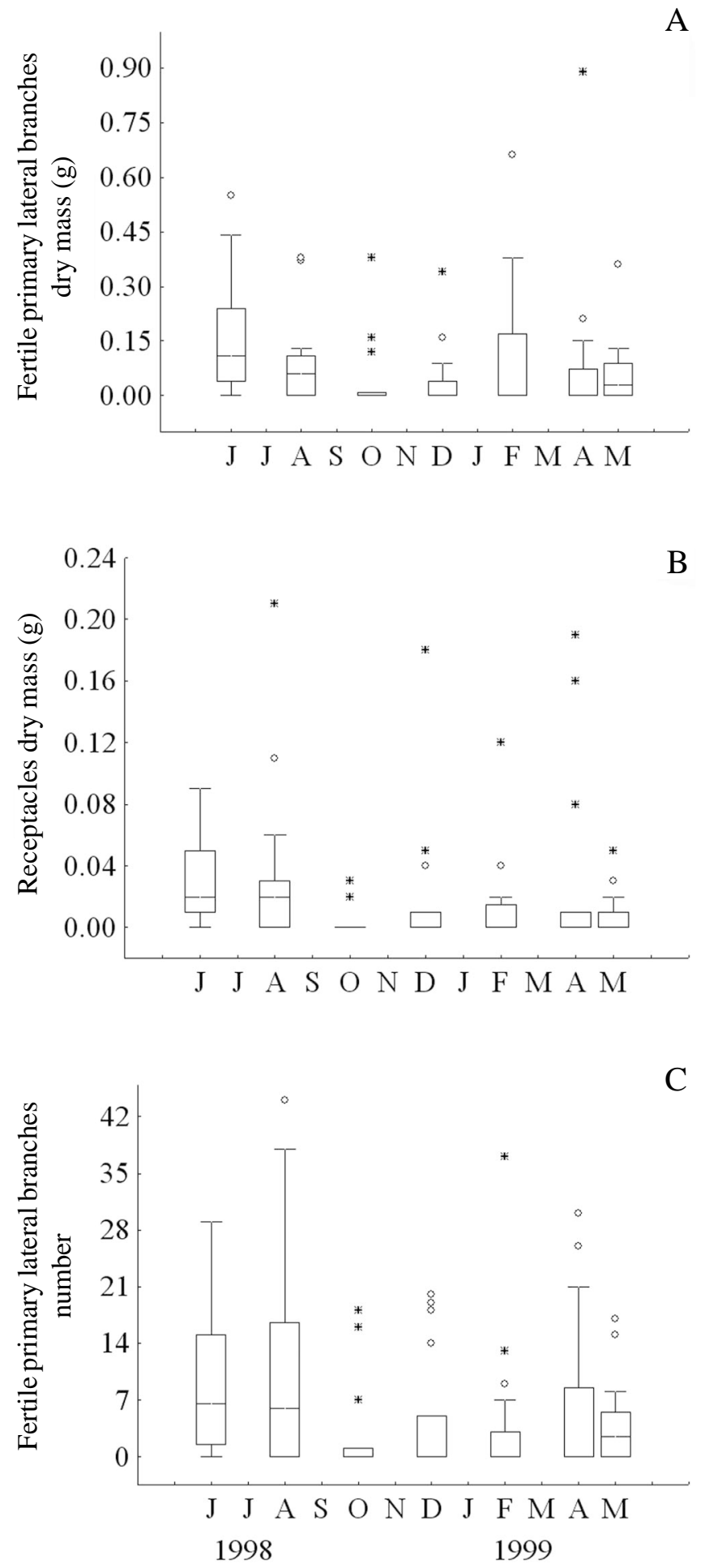

Figure 6. Boxplots representing the variation of the reproductive development in a Sargassum vulgare C. Agardh population from Angra dos Reis, based on reproductive variables. A. Fertile primary lateral branches dry mass per individual (g). B. Receptacles dry mass per individual (g). C. Fertile primary lateral branches number per individual. (Vertical lines = range of measurements; central boxes = inter-quartile ranges; central horizontal lines $=$ median values; $*$ and $\mathrm{O}=$ outlying values $)$. 
recruitment and growth of younger individuals (Kendrick \& Walker 1994), with less developed perennial parts. The effect of storm waves on the degree of vegetative development of Sargassum species is reported for other localities (Doty 1971, Rogers 1997, Calumpong et al. 1999).

The variation of median values of the vegetative variables related to the non-perennial parts throughout the study period suggests the spring-summer period as the most favorable to vegetative development of $S$. vulgare from Ilha Grande Bay (figure 3A-C). Although individual growth was not measured directly, it is likely that maximum growth rates in the population occurred two months before maximum dry mass values were obtained in February, according to other studies (McCourt 1984, Ang Junior 1985, Espinoza \& Rodríguez 1989, Martin-Smith 1993). This period of maximum growth rates (December 1998 to February 1999) coincided with the period without daytime minimum tides, and with higher air temperatures and rainfall. In the study area, higher rainfall in the summer had probably increased the nutrient concentration in the nearshore seawater, once organic material deposited in rivers and adjacent hills could be taken to the sea during the alluviones (Weber 1994), as suggested by the study of Lapointe (1997) on the nutrient availability for macroalgal blooms on coral reefs in Jamaica and southeastern Florida. The influence of higher air temperature and rainfall over the phenology of Sargassum species, although not experimentally tested, has been suggested as favorable to growth (Thomas \& Subbaramaiah 1991, Gillespie \& Critchley 1999). On the other hand, the high number of days with daytime minimum tides could have been one of the unfavorable factors for growth during the winter (June to August 1998), as individuals were probably exposed to more solar rays and winds, increasing their rate of water loss (Lobban \& Harrison 1997). According to Häder et al. (2001), a 30 minute exposure to solar irradiation caused a profound photoinhibition in the photosynthetic performance of $S$. vulgare from Canaria on site, from which the alga recovered only partially. That physiological stress can partially explain the decrease in the vegetative development of the individuals in the winter, as suggested by Ang Junior (1985) and Vuki \& Price (1994).

The temporal variation described for $S$. vulgare population from "Praia das Gordas" is similar to that described for other Brazilian species, such as $S$. cymosum C. Agardh var. cymosum from the states of São Paulo and Santa Catarina (Paula \& Oliveira Filho 1980, Dubiaski-Silva \& Masunari 2000), S. furcatum
Kuetzing (Godoy \& Coutinho 2002) and S. filipendula C. Agardh var. filipendula (Reis et al. 2003), from the state of Rio de Janeiro, as well as for species from other warm temperate regions, such as $S$. thunbergii (Mertens) O. Kuntze, S. johnstonii Setchell \& Gardner, S. herporhizum Setchell \& Gardner, S. sinicola Setchell \& Gardner var. camouii (Dawson) Norris \& Yensen, S. elegans Suhr (Umezaki 1974, McCourt 1984, Gillespie \& Critchley 1999). In contrast, the study carried out in Sepetiba Bay (Amado Filho et al. 2003) described maximum biomass values for different Sargassum species in spring as well as in winter and summer, depending on the sampling site, with no common favorable period for growth.

Some authors interpreted the variation in the development of Sargassum species throughout the year as a seasonal characteristic (Trono Junior \& Lluisma 1990, Largo et al. 1994, Rogers 1997, Hurtado \& Ragaza 1999). The following factors have been considered responsible for such seasonal variation in growth: water temperature, nutrient levels and day length (Prince \& O'Neal 1979, Ang Junior 1985, Gao 1990). These data are not available for the study area.

The simultaneous increase of vegetative and reproductive development in the $S$. vulgare population from "Praia das Gordas" agrees with the pattern of temporal variation previously documented for other populations of the genus (De Wreede 1976, Ang Junior 1985, Gillespie \& Critchley 1999). McCourt (1984) reported this fact and stated that each individual needs to achieve a critical height before becoming fertile.

The presence of fertile individuals all year round, as observed in this study, is common among the Brazilian Sargassum species (Paula \& Oliveira Filho 1980, Paula 1988, Széchy \& Cordeiro-Marino 1991), as well as among species from other regions of the world (De Ruyter van Steveninck \& Breeman 1987, Aguilar-Rosas \& Galindo 1990, Pacheco-Ruíz et al. 1998, Stiger \& Payri 1999). So, this qualitative variable seems to be not suitable for phenological studies of $S$. vulgare. On the other hand, the quantitative variables related to the reproductive development (proportion of fertile individuals, fertile primary lateral branches number, fertile primary lateral branches dry mass, receptacles dry mass and reproductive effort per individual) showed variation throughout the study period and their patterns of variation were similar, suggesting the consistency of these variables.

Although this $S$. vulgare population had individuals with receptacles at all the sampling times, the values of reproductive effort were lower than those calculated 
for other Fucales, especially those from cold waters, where the populations generally have a more evident reproductive season. Among eight perennial northwestern Atlantic fucoid taxa studied by Mathieson \& Guo (1992), seven taxa exhibited a pattern of high biomass allocation for reproduction (52\% to $62 \%$ ), except for the salt marsh ecad Ascophyllum nodosum (L.) Le Jolis ecad scorpioides (Reinke) Hauck. Fucus serratus L. from Scotland showed reproductive allocation of $38.6 \%$ and $50.5 \%$ for two reproductive annual events (Brenchley et al. 1996). The comparison of total reproductive efforts among three sympatric Sargassum species from the northern Gulf of California revealed widely different patterns: $6.9 \%$ in S. herporhizum to $74.0 \%$ in S. sinicola var. camouii (McCourt 1984). However, reproductive effort has to be cautiously analysed, since there is no common definition of this composed variable in the literature (Chapman 1986, Mathieson \& Guo 1992). The presence of receptacles must be considered with restriction for the recognition of fertile individuals, since there is no guarantee that their receptacles are ready to release gametes and to undergo sexual reproduction. Yoshida et al. (1998) described that the maturation period of two $S$. horneri C. Agardh populations from Hiroshima Bay, Japan, did not occur throughout the year, as the release of reproductive elements was noted only during some months. On the other hand, Paula \& Oliveira Filho (1980) showed that the release of reproductive elements in the S. cymosum population from Ubatuba occurred periodically throughout the year, coinciding with the spring tides. Mean fertility per population is a laborious but desirable quantitative variable for phenological studies, as have been done for some Sargassum species (Stiger \& Payri 1999).

Although phenological aspects of a $S$. vulgare population from Angra dos Reis, Ilha Grande Bay, have been described in this study, and some local abiotic factors were tentatively related to them, the causative factors of the observed variations will only be demonstrated by experimental data.

Among the quantitative variables analysed, those related to the non-perennial parts of the adult individuals were able to describe the vegetative and reproductive development of the population at the temporal scale adopted. Total dry mass, non-perennial parts dry mass, fertile primary lateral branches dry mass and receptacles dry mass were the most useful ones because they showed great variation throughout the study period but narrow ranges at each sampling time. Thallus height, usually employed in other phenological studies of
Sargassum, revealed lower coefficient of variation than those calculated for the variables related to dry mass. For some variables (e.g. primary lateral branches number, main axes maximum length and fertile primary lateral branches number), the wide variation ranges found among individuals at each sampling time make the definition of vegetative and reproductive peaks difficult, since comparisons between different sampling times are less accurate. This fact points out the need of previous calculations of the minimum sample size for phenological studies of Sargassum species.

Non-perennial parts dry mass and receptacles dry mass are recommended for phenological studies of $S$. vulgare, because they are suitable for temporal analyses. This methodological procedure avoids the sampling of the whole individual and warrants its regeneration from the perennial parts.

Acknowledgements - To Édison José de Paula (in memorian), for his valuable comments. To the "Fundação de Amparo à Pesquisa do Estado do Rio de Janeiro" - Faperj (processo ${ }^{\circ}$ E-26/152.560/2001) for the partial financial support.

\section{References}

AGUILAR-ROSAS, R. \& GALINDO, A.M. 1990. Ecological aspects of Sargassum muticum (Fucales, Phaeophyta) in Baja California, Mexico: reproductive phenology and epiphytes. Hydrobiologia 204/205:185-190.

AMADO FILHO, G.M., BARRETO, M.B.B.B., MARINS, B.V., FÉLIX, C. \& REIS, R.P. 2003. Estrutura das comunidades fitobentônicas do infralitoral da Baía de Sepetiba, RJ, Brasil. Revista Brasileira de Botânica 26:329-342.

ANG JUNIOR, P.O. 1985. Phenology of Sargassum siliquosum J. Ag. and S. paniculatum J. Ag. (Sargassaceae, Phaeophyta) in the reef flat of Balibago (Calatagan, Philippines). In Proceedings of V International Coral Reef Congress (V.M. Harmelin. \& B. Salvat, eds.). Antenne Museum- EPHE, Moorea, v.5, p.51-57.

BRENCHLEY, J.L., RAVEN, J.A. \& JOHNSTON, A.M. 1996. A comparison of reproductive allocation and reproductive effort between semelparous and iteroparous fucoids (Fucales, Phaeophyta). Hydrobiologa 326/327:185-190.

CALUMPONG, H.P., MAYPA, A.P. \& MAGBANUA, M. 1999. Population and alginate yield and quality assessment of four Sargassum species in Negro Island, central Philippines. Hydrobiologia 398/399:211-215.

CASTRO FILHO, B.M. 1994. Oceanografia física. In Diagnóstico ambiental oceânico e costeiro das regiões sul e sudeste do Brasil (Y. Ikeda, coord.). Petrobrás, Rio de Janeiro, v.3, p.4-253. 
CHAPMAM, A.R.O. 1986. Population and community ecology of seaweeds. In Advances in Marine Biology (J.H.S. Blaxter \& A.J. Southward, eds.). Academic Press, London. p.1-161.

DE RUYTER VAN STEVENINCK, E.D. \& BREEMAN, A.M. 1987. Population dynamics of a tropical intertidal and deep-water population of Sargassum polyceratium (Phaeophyceae). Aquatic Botany 29:139-156.

DE WREEDE, R.E. 1976. The phenology of three species of Sargassum (Sargassaceae, Phaeophyta) in Hawaii. Phycologia 15:175-183.

DOTY, M.S. 1971. Antecedent event influence on benthic marine algal standing crops in Hawaii. Journal of Experimental Marine Biology and Ecology 6:161-166.

DUBIASKI-SILVA, J. \& MASUNARI, S. 1995. Ecologia dos fitais de Caiobá, Matinhos, Paraná, Brasil. Revista Brasileira de Zoologia 12:373-396.

DUBIASKI-SILVA, J. \& MASUNARI, S. 2000. Variação sazonal e vertical da biomassa de Sargassum cymosum C. Agardh, 1820 (Phaeophyta) e da densidade de sua fauna vágil na Ponta das Garoupas, Bombinhas, Santa Catarina. Publicações da Academia de Ciências do Estado de São Paulo 109:110-117.

ESPINOZA, J. 1990. Estructura por edades y reproduccion de tres poblaciones de Sargassum sinicola (Phaeophyta, Fucales) en la Bahia de La Paz, Golfo de Califormia. Acta Botanica Mexicana 11:1-9.

ESPINOZA, J. \& RODRÍGUEZ, H. 1989. Growth of Sargassum sinicola Setchell et Gardner (Phaeophyta) in the southern Gulf of California, Mexico. Ciencias Marinas 15:141-149.

ESTON, V.R. \& BUSSAB, W.O. 1990. An experimental analysis of ecological dominance in a rocky subtidal macroalgal community. Journal of Experimental Marine Biology and Ecology 136:170-195.

FAGERBERG, W.R. \& DAWES, C.J. 1976. Studies on Sargassum, I: a light microscopic examination of the wound regeneration process in mature stipes of $S$. filipendula. American Journal of Botany 63:110-119.

GAO, K. 1990. Seasonal variation of photosynthetic capacity in Sargassum horneri. Japanese Journal of Phycology 38:25-33.

GILLESPIE, R.D. \& CRITCHLEY, A.T. 1999. Phenology of Sargassum spp. (Sargassaceae, Phaeophyta) from Reunion Rocks, KwaZulu-Natal, South Africa. Hydrobiologia 398/399:201-210.

GIVERNAUD, T., COSSON, J. \& GIVERNAUD-MOURADI, A. 1990. Régénération de la pheéophycée Sargassum muticum (Phéophycée, Fucale). Criptogamie Algologie 11:293-304.

GODOY, E.A.S. \& COUTINHO, R. 2002. Can artificial beds of plastic mimics compensate for seasonal absence of natural beds of Sargassum furcatum? ICES Journal of Marine Science 59:111-115.
HÄDER, D.-P., PORST, M. \& LEBERT, M. 2001. Photosynthetic performance of the Atlantic brown macroalgae, Cystoseira abies-marina, Dictyota dichotoma and Sargassum vulgare, measured in Gran Canaria on site. Environmental and Experimental Botany 45:21-32.

HURTADO, A.Q. \& RAGAZA, A.R. 1999. Sargassum studies in Currimao, Ilocos Norte, Northern Philippines, I: seasonal variations in the biomass of Sargassum carpophyllum J. Agardh, Sargassum ilicifolium (Turner) C. Agardh and Sargassum siliquosum J. Agardh (Phaeophyta, Sargassaceae). Botanica Marina 42:321-325.

KENDRICK, G.A. \& WALKER, D.I. 1994. Role of recruitment in structuring beds of Sargassum spp. (Phaeophyta) at Rottnest Island, western Australia. Journal of Phycology 30:200-208.

LAPOINTE, B.E. 1997. Nutrient thresholds for bottom-up control of macroalgal blooms on coral reefs in Jamaica and southeast Florida. Limnology and Oceanography 42:1119-1131.

LARGO, D.B., OHNO, M. \& CRITCHLEY,A.T. 1994. Seasonal changes in the growth and reproduction of Sargassum polycystum C. Ag. and Sargassum siliquosum J. Ag. (Sargassaceae, Fucales) from Liloan, Cebu, in Central Philippines. Japanese Journal of Phycology 42:53-61.

LOBBAN, C.S. \& HARRISON, P.J. 1997. Seaweed ecology and physiology. Cambridge University Press, Cambridge.

LÜNING, K. 1990. Seaweeds: their environment, biogeography, and ecophysiology. John Wiley \& Sons, New York.

MARTIN-SMITH, K.M. 1993. The phenology of four species of Sargassum at Magnetic Island, Australia. Botanica Marina 36:327-334.

MATHIESON, A.C. \& GUO, Z. 1992. Patterns of fucoid reproductive biomass allocation. British Phycological Journal 27:271-292.

MCCOURT, R.M. 1984. Seasonal patterns of abundance, distributions and phenology in relation to growth strategies of three Sargassum species. Journal of Experimental Marine Biology and Ecology 74:141-156.

NOGUEIRA, C.R., SILVA, V.M.A.P., BONECKER, S.L.C., BONECKER, A.C.T. \& NETO, G.S. 1987. Zooplancton da Baía da Ribeira (Angra dos Reis, RJ). Publicações Avulsas do Departamento de Zoologia do Instituto de Biologia da Universidade Federal do Rio de Janeiro 34:1-20.

OSTINI, S., SCORVO FILHO, J.D., KAWALL, H.G. \& BASTOS, A.A. 1992. Estudo preliminar da fixação primária do mexilhão Perna perna (Linnaeus, 1758) (Mollusca, Bivalva) em três espécies de algas de costão, na região de Ubatuba, SP. Boletim do Instituto de Pesca 19:119-125. 
PACHECO-RUÍZ, I., ZERTUCHE-GONZÁLEZ, J.A., CHEEBARRAGÁN, A. \& BLANCO-BETANCOURT, R. 1998. Distribution and quantification of Sargassum beds along the west coast of the Gulf of California, Mexico. Botanica Marina 41:203-208.

PAULA, É.J. 1988. Gênero Sargassum C. Ag. (PhaeophytaFucales) no litoral do estado de São Paulo, Brasil. Boletim de Botânica da Universidade de São Paulo 10:65-118.

PAULA,É.J. \& ESTON, V.R. 1987. Are there other Sargassum species potentially as invasive as $S$. muticum? Botanica Marina 30:405-410.

PAULA, É.J. \& OLIVEIRA FILHO, E.C. 1980. Aspectos fenológicos de duas populações de Sargassum cymosum (Phaeophyta- Fucales) do litoral de São Paulo, Brasil. Boletim de Botânica da Universidade de São Paulo 8:21-39.

PEREIRA, C.S. 1994. Meteorologia. In Diagnóstico ambiental oceânico e costeiro das regiões sul e sudeste do Brasil (Y. Ikeda, coord.). Petrobrás, Rio de Janeiro, v.2, p.243-347.

PRINCE, J.S. \& O'NEAL, S.W. 1979. The ecology of Sargassum pteropleuron Grunow (Phaeophyceae, Fucales) in the waters off South Florida, I: growth, reproduction and population structure. Phycologia 18:109-114.

REIS, R.P., LEAL, M.C.R., YONESHIGUE-VALENTIN, Y. \& BELLUCO, F. 2003. Efeito de fatores bióticos no crescimento de Hypnea musciformis (Rhodophyta Gigartinales). Acta Botanica Brasilica 17:279-286.

ROGERS, R.W. 1997. Brown algae on Heron Reef Flat, Great Barrier Reef, Australia: spatial, seasonal and secular variation in cover. Botanica Marina 40:113-117.

STIGER, V. \& PAYRI, C.E. 1999. Spatial and seasonal variations in the biological characteristics of two invasive brown algae, Turbinaria ornata (Turner) J. Agardh and Sargassum mangaravense (Grunow) Setchell (Sargassaceae, Fucales) spreading on the reefs of Tahiti (French Polynesia). Botanica Marina 42:295-306.

SZÉCHY, M.T.M. \& CORDEIRO-MARINO, M. 1991. Feofíceas do litoral norte do estado do Rio de Janeiro, Brasil. Hoehnea 18:205-241.
SZÉCHY, M.T.M. \&. PAULA, E.J. 2000. Padrões estruturais quantitativos de bancos de Sargassum (Phaeophyta, Fucales) do litoral dos estados do Rio de Janeiro e São Paulo, Brasil. Revista Brasileira de Botânica 23:121-132.

SZÉCHY, M.T.M., VELOSO, V.G. \& PAULA, E.J. 2001. Brachyura (Decapoda, Crustacea) of phytobenthic communities of the sublittoral region of rocky shores of Rio de Janeiro and São Paulo, Brazil. Tropical Ecology 42:231-242.

THOMAS, P.C. \& SUBBARAMAIAH, K. 1991. Seasonal variations in growth, reproduction, alginic acid, mannitol, iodine and ash contents of brown alga Sargassum wightii. Indian Journal of Marine Sciences 20:169-175.

TOMMASI, L.R. 1990. Efeitos antrópicos sobre o ecossistema marinho das regiões sudeste-sul do Brasil. In Anais do II Simpósio de Ecossistemas da Costa Sul e Sudeste Brasileira: estrutura, função e manejo (S. Watanabe, coord.). Academia de Ciências do Estado de São Paulo, São Paulo, v.1, p.53-54.

TRONO JUNIOR, G.C. \& LLUISMA, A.O. 1990. Seasonality of standing crop of a Sargassum (Fucales, Phaeophyta) bed in Bolinao, Pangasinan, Philippines. Hydrobiologia 204/205:331-338.

UMEZAKI, I. 1974. Ecological studies of Sargassum thunbergii (Mertens) O. Kuntze in Maizuru Bay, Japan Sea. Botanical Magazine 87:285-292.

UMEZAKI, I. 1984. Ecological studies of Sargassum hemiphyllum C. Agardh in Obama Bay, Japan Sea. Bulletin of the Japanese Society of Scientific Fisheries 50:1677-1683.

VUKI, V.C. \& PRICE, I.R. 1994. Seasonal changes in the Sargassum populations on a fringing coral reef, Magnetic Island, Great Barrier Reef region, Australia. Aquatic Botany 48:153-166.

WEBER, R.R. 1994. Oceanografia química. In Diagnóstico ambiental oceânico e costeiro das regiões sul e sudeste do Brasil (Y. Ikeda, coord.). Petrobrás, Rio de Janeiro, v.3, p.254-363.

YOSHIDA, G., ARIMA, S. \& TERAWAKI, T. 1998. Growth and maturation of the 'autumn-fruiting type' of Sargassum horneri (Fucales, Phaeophyta) and comparisons with the 'spring-fruiting type'. Phycological Research 46:184-189. 